University of Nebraska - Lincoln

DigitalCommons@University of Nebraska - Lincoln

$10-1980$

\title{
Distribution of Plants with Extrafloral Nectaries in Temperate Communities
}

Kathleen H. Keeler

University of Nebraska - Lincoln, kkeeler1@unl.edu

Follow this and additional works at: https://digitalcommons.unl.edu/bioscifacpub

Keeler, Kathleen H., "Distribution of Plants with Extrafloral Nectaries in Temperate Communities" (1980). Faculty Publications in the Biological Sciences. 281.

https://digitalcommons.unl.edu/bioscifacpub/281

This Article is brought to you for free and open access by the Papers in the Biological Sciences at DigitalCommons@University of Nebraska - Lincoln. It has been accepted for inclusion in Faculty Publications in the Biological Sciences by an authorized administrator of DigitalCommons@University of Nebraska - Lincoln. 


\title{
Distribution of Plants with Extrafloral Nectaries in Temperate Communities
}

\author{
KATHLEEN H. KEELER \\ School of Life Sciences, University of Nebraska, Lincoln, Nebraska 68588
}

\begin{abstract}
The abundance of plants with extrafloral nectaries was determined for a series of temperate habitats in Nebraska. Mean cover of plants with extrafloral nectaries was $1.3 \%$ in riparian forest understory, $1.8 \%$ in virgin deciduous forest understory, $0.0 \%$ in tall-grass prairie, and $8.3 \%$ in sandhill prairie. Sandhills prairie contained distinct communities with different mean cover of plants with extrafloral nectaries and showed seasonal changes in nectary activity. Cover of plants with extrafloral nectaries was compared to ant abundance, plant species diversity, rainfall and frost-free season: the first two showed highly significant correlations with mean cover of extrafloral nectaries.
\end{abstract}

\section{INTRODUCTION}

Extrafloral nectaries (EFNs) are nectar-secreting glands found in a plant outside the flower. Generally, many nectar-feeding insects, especially ants, wasps, flies and beetles, are attracted to EFNs (e.g., Keeler, 1978). Available studies have shown EFN visitors to provide protection to the plant from damage, including flowerrobbing (Elias and Gelband, 1975; Keeler, 1977), seed loss (Bentley, 1977b; Deuth, 1977; Inouye and Taylor, 1979; Keeler, 1980; Pickett and Clark, 1979) and leaf damage (Keeler, 1977; Tilman, 1978). Bentley (1977a) reviewed the literature regarding protection of plants by EFNs.

Little is known about the distribution and abundance of plants with EFNs. Bentley (1976) reported the frequency of plants with EFNs ranged from 0.1 to 0.8 in riparian forest and tropical dry forest sites in Guanacaste, Costa Rica. . In Jamaica, Keeler (1979a) found the frequency of plants with EFNs to be 0.28 at sea level and 0.00 at $1310 \mathrm{~m}$. Gilbert (quoted in Orians, 1974) and Bentley (1977a) have suggested that EFN-bearing plants are proportionately more common in tropical than temperate regions. This view is supported by Keeler (1979b) who found $3 \%$ of the species in the flora of Nebraska had EFNs. This paper reports the first data on the abundance of plants with EFNs in temperate habitats and considers possible causes of this distribution.

\section{Methods and Sites}

All study sites were located in Nebraska, $92^{\circ} 25^{\prime}-104^{\circ} \mathrm{W}, 40-43^{\circ} \mathrm{N}$. The climate is strongly continental, with annual temperatures frequently ranging from $40 \mathrm{C}$ to $-34 \mathrm{C}$. Rainfall is low: from $35 \mathrm{~cm} /$ year in the $\mathrm{W}$ to $100 \mathrm{~cm} /$ year in the SE. Most of the area was originally prairie, with a small amount of forest along rivers in the $\mathrm{E}$ and in the hills of the northwestern part of the state.

Study sites used were at five locations: (1) Fontenelle Forest, Douglas Co., elevation $350 \mathrm{~m}$; a stand of virgin temperate deciduous forest (oak/hickory) on the bluffs along the Missouri River was studied in this privately owned park. (2) Reller Natural History Study Area, Lancaster Co., elevation $380 \mathrm{~m}$; this area is ca. 30 acres of riparian ash and walnut forest close to Lincoln, Nebraska, owned by the University of Nebraska. (3) Twin Lakes Prairie, Seward Co., $425 \mathrm{~m}$; this is a tall-grass prairie remnant in eastern Nebraska owned by the Nebraska Game and Parks Commission. (4) Madigan Prairie, Saunders Co., $425 \mathrm{~m}$; this is a remnant tall-grass prairie (ca. 20 acres) in eastern Nebraska, managed by the University of Nebraska; both tall-grass prairies are dominated by Andropogon gerardii, A. scoparius and Sorghastrum avenaceum. (5) Arapaho Prairie, Arthur Co., $1130 \mathrm{~m}$; this is a 1390 . acre reserve of sandhills prairie in western Nebraska, owned by the Nature Con- 
servancy. Sandhills prairie is a mixed prairie, dominated by Stipa comata, Andropogon spp. and Koeleria cristata. It differs in species composition from other mixed prairies due to the sand substrate.

To determine how abundant individuals with EFNs are in natural ecosystems, percent cover contributed by plants with EFNs was determined. Initially, canopycover data, estimating per cent cover of a quadrat $\left(.1 \mathrm{~m}^{2}\right)$ were collected (Daubenmire, 1959). However, estimates of cover in sparse communities inevitably include a considerable fraction of bare ground. Since the study was concerned with relative proportions of plants with and without EFNs, factoring out the bare ground was necessary. Subsequently, a point-intercept method was adopted, recording plants nearest to randomly chosen points on a transect, thereby eliminating problems with the bare-ground cover class. In the percent cover analysis, plants of 300 quadrats $\left(30 \mathrm{~m}^{2}\right)$ were assigned abundances (Daubenmire, 1959) and identified. By the point-intercept method, 8199 points were chosen and the nearest plant recorded.

Individual plants encountered were identified and the number with EFNs was determined: (1) by observing nectar-feeding insect activity on the plants and subsequently locating the nectary, and (2) from published lists of species with EFNs (e.g., Zimmermann, 1932; Bentley, 1977a; Keeler, 1979b). A list of Nebraska plants with EFNs is found in Keeler (1979b). A functional definition of EFN was used: a nectary was considered present if nectar was secreted, whether or not a specialized structure was present (see, e.g., Tilman, 1978). Nectaries that are structurally outside the flower but which function in pollination were excluded (e.g., nectaries of the inflorescence of Asclepias syriaca and Euphorbia marginata).

Ant abundance at each site was monitored with baiting studies. Small amounts (ca. $1 \mathrm{~cm}^{3}$ ) of tuna fish and corn syrup were placed on $2 \mathrm{~cm}^{2}$ pieces of plastic every $2 \mathrm{~m}$ along the transects. Ant visitors were recorded after 15, 30, 60, 120 and $180 \mathrm{~min}$. Air temperatures were noted.

Baiting was carried out at the same time as transect analysis at all sites except the sandhills prairie. In the sandhills sites, the vegetation analysis data were collected 3-4 September 1977, and the ant baiting was done 30 June 1978. 'The ant data is relevant to the plant data because the same segment of the flora is active during this period and because EFNs secreting when the ant baiting was carried out (specifically, the ephemeral EFNs of Yucca glauca) were included. Since the plants are sparse (absolute cover only reaches $70-80 \%$ at the end of the growing season), there is probably little change in relative cover as the warm season flora matures.

Climatic data were taken from Lawson et al. (1977).

Species diversity was calculated using Shannon's index $\left(\mathrm{H}^{\prime}\right)$ (Lloyd et al., 1968). Actual transect data from each site were used in the calculations.

\section{Distribution of Plants with Extrafloral Negtaries}

Tall-grass prairie had the smallest percent cover with EFNs $(0.0 \%)$ (Table 1).

TABLE 1.--Percent cover of plants with extrafloral nectaries in Nebraska habitats

\begin{tabular}{lccc}
\hline \hline Habitat & $\begin{array}{c}\text { Percent cover of } \\
\text { plants with EFNs }\end{array}$ & $\begin{array}{c}\text { 95\% c.l. } \\
\text { of mean }^{\prime}\end{array}$ & $\begin{array}{c}\text { No. species with } \\
\text { with EFNs in }^{\text {habitat }}\end{array}$ \\
\hline Deciduous forest understory & $1.8(22 / 1219)^{\mathrm{c}}$ & $0-4.0$ & 22 \\
Riparian forest understory & $1.3(18 / 1456)^{\mathrm{c}}$ & $0-4.7$ & 27 \\
Tall-grass prairie & $0.0(0 / 2624)^{\mathrm{c}}$ & undefined & 13 \\
Sandhills prairie & $8.3(240 / 2900)^{\mathrm{d}}$ & $0-45.6$ & 11 \\
\hline
\end{tabular}

a Keeler, 1979b

b Includes both Twin Lakes and Madigan Prairie sites

c Point intercept

d Percent cover 
The riparian forest understory transects had a mean cover with EFNs of $1.3 \%$. The deciduous forest understory mean was $1.8 \%$. Sandhills prairie had a mean cover of plants with EFNs of 8.3\%. Confidence limits on the first three communities are fairly narrow. They are not statistically different from one another, although it is possible that tall-grass prairie is in fact poorer in plants with EFNs than the other communities. Mean cover of plants with EFNs in sandhills prairie lies outside the $95 \%$ confidence interval of the other habitats.

The sandhills prairie was not uniform, as suggested by the broad $95 \%$ confidence interval. Because of this, the three major habitats of the prairie (A. T. Harrison, pers. comm.) were compared for cover by plants with EFNs (Table 2). The three habitats correspond roughly to dune tops, hillsides and valley bottoms, dominated by (a) Calamovilfa longifolia, Koeleria cristata and Andropogon hallii; (b) C. longifolia and Stipa comata, and (c) S. comata and Bouteloua hirsuta, respectively. Sampling was carried out in spring (May) and late summer (early September). The numbers given are the coverage of plants with functional EFNs at that season.

The values cited for habitats are the results of transects made of several hundred to over 1000 points. In small areas, all individuals have EFNs, for example, in patches of Yucca glauca or Helianthus grosseserratus or thickets of Prunus americana. Regional averages must therefore be treated with care and may not reflect the significant aspects of community organization.

Tall-grass prairie does not actually lack species with EFNs even though none were encountered in the vegetation analysis of 2624 points. There are at least 13 species characteristic of tall-grass prairie with EFNs [(e.g., Cassia fasciculata (Fabaceae), Helianthus grosseserratus (Asteraceae)] (Keeler, 1979b). All the other habitats also had species with EFNs that were present but not encountered in the vegetation analysis. Clearly, species with EFNs are relatively rare. However, other species (without EFNs) were present but not encountered in the survey. Therefore, probably the important fact is that common plants in Nebraska ecosystems lack EFNs.

The view of Gilbert (in Orians, 1974) and Bentley (1977a) that plants with EFNs are more common in tropical than temperate regions appears to hold. Bentley (1976) and Keeler (1979a) reported values for tropical sites ranging from 0.0-0.8, most of which are higher than the highest value reported here $(14.2 \%)$.

The seasonal differences in nectary activity are intriguing. Mainly, seasonality results from ephemeral nectaries: either foliar EFNs which only function briefly, or EFNs associated with a distinct flowering season. With the possible exception of Prunus spp., transitory nectaries were not seen in forest understory transects. Some tall-grass prairie species with EFNs show seasonal nectary function (e.g., Cassia fasciculata), but none of these were encountered in the transects, so their importance cannot be evaluated.

It would be interesting to know if seasonality of EFNs is widespread in temperate environments. Certainly distinct seasonality is suggested for the EFNs of Prunus

TABLE 2.-Percent cover of plants with EFNs in sandhills prairie communities. Arapaho Prairie, Arthur Co., Nebraska

\begin{tabular}{lcc}
\hline \hline Community & \multicolumn{2}{c}{ Percent cover of plants with EFNs $^{\mathrm{a}}$} \\
& Spring & Late \\
& summer \\
\hline Dune tops & 0.2 & $6.8^{\mathrm{b}}$ \\
Hillside & 2.0 & 11.1 \\
Valley & 0.4 & 0.1 \\
\hline
\end{tabular}

a Based on percent cover of $.1 \mathrm{~m}^{2}$ quadrats (Daubenmire 1959)

b This value is for August-September. In July the presence of EFNs on pods of Yucca glauca (Liliaceae), raises this to $14.2 \%$ 
serotina (Tilman, 1978) and Helianthella quinquenervis (Inouye and Taylor, 1979). The other temperate species studied in the literature, Campsis radicans (Elias and Gelband, 1975), has a series of EFNs which probably maintain nectar production throughout the growing season.

\section{Causes of the Distribution of Extrafloral Negtaries}

Very little is known about the causes of the distribution of EFNs. Bentley (1977a) argues that EFNs, in general, function in an ant-plant mutualism. Therefore, the distribution of EFNs should be related to the distribution of ants. Most studies support ant-plant mutualism (Elias and Gelband, 1975; Bentley, 1976, 1977b; Keeler, 1977, 1980; Deuth, 1977; Tilman, 1978; Inouye and Taylor, 1979; Pickett and Clark, 1979). However, that all EFNs are part of a mutualism with ants is a major extrapolation from a few cases.

An alternative function of EFNs might be to adapt the plant to the physical environment. Consequently, EFN distribution should correlate with climate. A third alternative is that EFN function is not related to the plant's ecology. That is, EFNs show no simple pattern within a region, as in the case, for example, with the number of petals per flower or alternate vs. opposite leaves. In this case there would be no correlation of the trait with either biotic or abiotic components of the environment.

These alternatives are complex and may not be mutually exclusive. However, in an attempt to evaluate their importance, cover of EFNs in Nebraska was compared to a series of variables: (A) ant abundance; (B) climate, and (C) plant species diversity.

(A) Ant abundance.-The distribution of EFNs as an ant-plant mutualism should be related to ant abundance. Ant abundance at the sites was monitored by baiting, and the data scored as: (1) percent baits found after $60 \mathrm{~min}$; (2) percent baits found after $180 \mathrm{~min}$; (3) mean peak number of ants per pair of baits, and (4) mean number of ant species per bait. All of these values correlated positively with frequency of EFNs, the correlations being, respectively, (1), 0.263, (2) 0.334, (3) 0.649 , and (4) 0.805 . The most highly correlated value, mean number of ant species attracted, was used in stepwise multiple regression with other possible causes (Tables 3 and 4 ).

An estimate of "herbivore load" against which the plants might be defending themselves would have been useful, but no data were collected on that topic.

(B) Climate.-All study sites were in a strongly temperate climate with wide temperature extremes. Sites differed in length of growing season (frost-free season, Table 3) ranging from 185 frost-free days per year in the deciduous forest sites to

TABLE 3.-Percent cover of extrafloral nectaries, response of ants to baits, rainfall, frostfree season and plant species diversity at 10 sites $^{\mathrm{a}}$

\begin{tabular}{lccccr}
\hline \hline Habitat & $\begin{array}{c}\text { Percent } \\
\text { cover, } \\
\text { EFN }\end{array}$ & $\begin{array}{c}\text { Mean no. } \\
\text { ant species } \\
\text { per bait }\end{array}$ & $\begin{array}{c}\text { Rainfall } \\
\text { (in cm/ } \\
\text { year) }\end{array}$ & $\begin{array}{c}\text { Frost-free } \\
\text { season } \\
\text { (days) }\end{array}$ & H' $^{\text {b }}$ \\
\hline Riparian forest & 0.7 & 1.82 & 62 & 175 & 1.00 \\
Riparian forest & 0.3 & 2.00 & 62 & 175 & 1.16 \\
Riparian forest & 3.8 & 1.94 & 62 & 175 & 1.00 \\
Deciduous forest & 2.5 & 1.88 & 80 & 185 & 1.36 \\
Deciduous forest & 1.0 & 2.20 & 80 & 185 & 1.27 \\
Tall-grass prairie & 0.0 & 2.50 & 62 & 175 & 0.44 \\
Tall-grass prairie & 0.0 & 2.08 & 62 & 165 & 0.45 \\
Tall-grass prairie & 0.0 & 2.84 & 62 & 165 & 0.46 \\
Sandhills prairie & 1.0 & 3.27 & 41 & 165 & 0.80 \\
Sandhills prairie & 14.2 & 5.11 & 41 & 165 & 1.33 \\
\hline
\end{tabular}

a $\mathrm{See}$ text for methods

b 30-year means 
165 days in two tall-grass prairie and the sandhills prairie sites (Lawson et al., 1977). Sites also differed in rainfall, decreasing from $80 \mathrm{~cm} /$ year (30-year average) in deciduous forest to $42 \mathrm{~cm} /$ year in sandhills prairie (Table 3). The importance of these variables to the distribution of EFNs was evaluated using stepwise multiple regression (Table 4).

(C) Other.-Nonecological causes of the distribution of EFNs (e.g., taxonomic affinities, history) might produce a uniform distribution of EFNs across the study areas, and/or no detectable correlation with biotic or climatic variables. The abundance of EFNs might also vary predictably between habitats because of variation in plant species in the habitat, while having nothing to do with the adaptive value of EFNs. This was evaluated by comparing EFNs to $\mathrm{H}^{\prime}$ values for each of the transects (Tables 3 and 4 ).

Eighty percent of the variance in cover of EFNs (Table 4) is explained by ant response to baits $(\mathrm{F}=14.771,0.01>\mathrm{p}>0.005), 11 \%$ by plant species diversity at the sites $(\mathrm{F}=6.786,0.005>\mathrm{p}>0.025), 1 \%$ by frost-free season and less than $1 \%$ by rainfall ( $\mathrm{F}=0.094$ and 0.081 , respectively, not significant $)$.

These data strongly support the relationship with ant abundance. Although correlation cannot establish causation and the most important variable may not have been included in the analysis, there is, nevertheless, a striking, highly significant relationship between the abundance of ants and the cover of EFNs. This is consistent with all the work claiming EFNs are part of an ant-plant mutualism.

No relationship with climatic differences was seen. There is also no relationship between EFN-cover and habitat type: grassland communities have the highest and lowest percent EFN cover, with forest understory intermediate. It is improbable that the distribution of EFNs in Nebraska is due to differential advantages of the trait under different climatic conditions. Macroclimatic differences may be more important on a global scale, but more work is needed.

The significant relationship with species diversity is problematic. The correlation between $\mathrm{H}^{\prime}$ and percent cover of plants with EFNs is positive, $\mathrm{r}=0.514$. The biological meaning of the observation that more of the relatively rare species are likely to have EFNs in a more diverse community is not obvious. Perhaps this implies some subtlety of community organization.

It is not clear what the correlation between ants and EFNs means. Plants with EFNs which evolved or immigrated in response to a particular ant density might provide an additional food resource for ants, allowing increase in ant density, which would allow selection or immigration of additional plants with EFNs, etc. This should continue to some limit, when nectar and its micronutrients no longer limit ant density but some other factor comes into play. The question may hinge on the ant carrying capacity of different areas. Ant abundance must ultimately be related to the abundance of competing taxa (e.g., Brown and Davidson, 1977) and the type and number of nest sites available, as well as food availability. There is not a great

TABLE 4.-Stepwise multiple regression of percent cover of extrafloral nectaries against ant response to baits, rainfall frost-free season and plant species diversity

\begin{tabular}{lcccc}
\hline \multicolumn{2}{c}{ ant response to baits, rainfall frost-free season and plant species diversity } \\
& $\begin{array}{c}\mathrm{R}^{2} \\
\text { Proportion } \\
\text { reduced }\end{array}$ & $\begin{array}{c}\text { F of } \\
\text { variable }\end{array}$ & $\begin{array}{c}\text { Multiple } \\
\text { R }\end{array}$ \\
\hline Mean no. ant species/bait & .648 & $14.711^{* *}$ & .80 & $1_{\text {for }}^{*}$ \\
$H^{\prime}$ & .173 & $6.785^{*}$ & .91 & $11^{* *}$ \\
Frost-free season & .003 & 0.094 & .91 & $9.357^{* *}$ \\
Rainfall & .003 & 0.081 & .91 & $5.963^{*}$ \\
\hline
\end{tabular}

* Statistically significant at the $5 \%$ level

** Statistically significant at the $1 \%$ level 
deal known about the abundance of ants in different areas (Pisarski, 1978), let alone its regulation.

Plants using EFNs for antiherbivore defense must fit into their respective community's array of plant defenses. Thus, they are subject to considerations of optimal foraging strategy by herbivores (Cates and Orians, 1975; Feeny, 1976; Rhoades and Cates, 1976). An ant guard attracted to EFNs would seem a relatively economical and general antiherbivore defense. However, as a defense, ants are less reliable than secondary chemicals or morphological defenses since they are not always present. Ants are more effective against small, soft-bodied insects than against large, hardbodied ones. In general, they are ineffective against vertebrates. Perhaps the effectiveness of the protection and the types of herbivores in the community, as well as carrying capacity of ants, affect the percent cover by plants with EFNs. More information on distribution of plants with EFNs, ants and herbivores will be needed to evaluate these ideas.

Acknowledgments.-I wish to thank L. S. Vescio, K. C. Kruse, D. L. Mahoney and the students in Quantitative Field Ecology, 1977, for collecting the Daubenmire square cover estimates. I thank A. Joern and R. Ballinger for useful discussion. J. Ballard, Department of Entomology, University of Nebraska, Lincoln, kindly identified the ants. I want to thank the administrators of the Arapaho Prairie, Madigan Prairie, Fontenelle Forest and Twin Lakes Prairie for their cooperation. This work would not have been possible without the support of $\mathrm{K}$. Anderson. The research was supported in part by the University of Nebraska, Lincoln, Research Council and in part by the National Science Foundation Research Initiation and Support Grant SER-77 06931.

\section{Literature Gited}

Bentley, B. L. 1976. Plants bearing extrafloral nectaries and the associated ant community: interhabitat differences in the reduction of herbivore damage. Ecology, 57:815-820.

-. 1977a. Extrafloral nectaries and protection by pugnacious bodyguards. Annu. Rev. Ecol. Syst., 8:407-427.

- $1977 \mathrm{~b}$. The protective function of ants visiting the extrafloral nectaries of Bixa orellana (Bixaceae). J. Ecol., 65:17-38.

Brown, J. H. AND D. W. Davidson. 1977. Competition between seed-eating rodents and ants in desert ecosystems. Science, 196:880-882.

Cates, R. G. and G. H. Orians. 1975. Successional status and the palatability of plants to generalized herbivores. Ecology, 56:410-418.

Daubenmire, R. F. 1959. Canopy coverage method of vegetation analysis. Northwest Sci., 33 : 43-64.

Deuth, D. 1977. The function of extra-floral nectaries in Aphelandra deppeana Schl. \& Cham. (Acanthaceae). Brenesia, 10/11:135-145.

Elias, T. S. and H. Gelband. 1975. Nectar: its production and function in trumpet creeper. Science, $189: 289-290$.

Feeney, P. P. 1976. Plant apparency and chemical defense. Recent Adv. Phytochem., 10: $1-40$.

Greig-Smith, P. 1964. Quantitative plant ecology, 2nd ed. Butterworths, Washington, D.C. $256 \mathrm{p}$.

InOUye, D. W. ANd O. R. TAYlor. 1979. A temperate region plant-ant-seed predator system: consequences of extra floral nectar secretion by Helianthella quinquenervis. Ecology, $60: 1-7$.

Keeler, K. H. 1977. The extrafloral nectaries of I pcmoea carnea (Convolvulaceae). Am. J. Bot., 64:1182-1188.

- 1978. Insects feeding at extrafloral nectaries of Ipomoea carnea (Convolvulaceae). Entomol. News, 89:163-168.

. 1979a. Distribution of plants with extrafloral nectaries and ants at two elevations in Jamaica. Biotropica, $11: 152-154$.

1979b. Species with extrafloral nectaries in a temperate flora (Nebraska). Prairie Nat., $11: 33-38$. 
1980. The extrafloral nectaries of Ipomoea leptophylla (Convolvulaceae). Am. J. Bot. $67: 216-222$.

Lawson, M. P., K. F. Dewey and R. E. Neild. 1977. Climatic atlas of Nebraska. University of Nebraska Press, Lincoln. 88 p.

Lloyd, M., J. H. ZAR AND J. R. KARR. 1968. On the calculation of information-theoretical measures of diversity. Am. Midl. Nat. 79:257-272.

Orians, G. 1974. Tropical pollination ecology, p. 5-66. In: E. G. Farnworth and F. B. Golley (eds.). Fragile ecosystems. Evaluation of research and applications in the neotropics. Springer-Verlag, Heidelberg.

Pigkett, G. H. and W. D. Glark. 1979. The function of extrafloral nectaries in Opuntia acanthocarpa (Cactaceae). Am. J. Bot., 66:618-625.

Pisarski, B. 1978. Comparison of various biomes, p. 326-341. In: M. V. Brian (ed.). Production ecology of ants and termites. Cambridge University Press, New York.

Rhoades, D. F. and R. G. Cates. 1976. Toward a general theory of plant antiherbivore chemistry. Recent Adv. Phytochem., 10:168-213.

Tilman, D. 1978. Cherries, ants and tent caterpillars: Timing of nectar production in relation to susceptibility of caterpillars to ant predation. Ecology, 59:686-692.

Zimmermann, J. 1932. Ueber die extraflorale Nectarien der Angiospermen. Bot. Centr. Beih., 49:99-196.

Submitted 22 June 1979

AgGepted 29 October 1979 